OPEN ACCESS

Approved by:

Frontiers Editorial Office,

Frontiers Media SA, Switzerland

*Correspondence:

Ángela Mosquera Giménez angela.mosquera@ieo.es;

angela_mosq@hotmail.com

Specialty section:

This article was submitted to Deep-Sea Environments and Ecology,

a section of the journal

Frontiers in Marine Science

Received: 09 February 2021 Accepted: 10 February 2021

Published: 25 February 2021

Citation:

Mosquera Giménez Á, Vélez-Belchí $P$, Rivera J, Piñeiro S, Fajar N, Caínzos V,

Balbín R, Jiménez Aparicio JA, Dominguez-Carrió C, Blasco-Ferre J, Carreiro-Silva M, Morato T, Puerta P and Orejas $C$ (2021) Corrigendum: Ocean Circulation Over North Atlantic Underwater Features in the Path of the Mediterranean Outflow Water: The Ormonde and Formigas Seamounts, and the Gazul Mud Volcano.

Front. Mar. Sci. 8:665980.

doi: 10.3389/fmars.2021.665980

\section{Corrigendum: Ocean Circulation Over North Atlantic Underwater Features in the Path of the Mediterranean Outflow Water: The Ormonde and Formigas Seamounts, and the Gazul Mud Volcano}

\author{
Ángela Mosquera Giménez ${ }^{1 *}$, Pedro Vélez-Belchí ${ }^{1}$, Jesús Rivera ${ }^{2}$, Safo Piñeiro ${ }^{3}$, \\ Noelia Fajar ${ }^{4}$, Verónica Caínzos ${ }^{5}$, Rosa Balbín ${ }^{3}$, Juan Antonio Jiménez Aparicio ${ }^{3}$, \\ Carlos Dominguez-Carrió ${ }^{6}$, Jordi Blasco-Ferre ${ }^{6}$, Marina Carreiro-Silva ${ }^{6}$, Telmo Morato ${ }^{6}$, \\ Patricia Puerta ${ }^{3}$ and Covadonga Orejas ${ }^{3}$
}

${ }^{1}$ Centro Oceanográfico de Canarias, Instituto Español de Oceanografía, Santa Cruz de Tenerife, Spain, ${ }^{2}$ Servicios Centrales, Instituto Español de Oceanografía, Madrid, Spain, ${ }^{3}$ Centro Oceanográfico de Baleares, Instituto Español de Oceanografía, Palma, Spain, ${ }^{4}$ Centro Oceanográfico de a Coruña, Instituto Español de Oceanografía, A Coruña, Spain, ${ }^{5}$ IOCAG, Universidad de Las Palmas de Gran Canaria, Instituto de Oceanografiia y Cambio Global, ULPGC, Unidad Asociada ULPGC-CSIC, Las Palmas de Gran Canaria, Spain, ${ }^{6}$ Marine and Environmental Sciences Centre, Centro OKEANOS, Instituto Do Mar, Universidade dos Açores, Horta, Portugal

Keywords: seamounts, Mediterranean Outflow Water, Taylor columns/caps, internal waves, cold-water corals

\section{A Corrigendum on}

Ocean Circulation Over North Atlantic Underwater Features in the Path of the Mediterranean Outflow Water: The Ormonde and Formigas Seamounts, and the Gazul Mud Volcano by Mosquera Giménez, Á., Vélez-Belchí, P., Rivera, J., Piñeiro, S., Fajar, N., Caínzos, V., et al. (2019). Front. Mar. Sci. 6:702. doi: 10.3389/fmars.2019.00702

In the original article, there was a mistake in Figure 14 as published. The gray dashed line mentioned in the legend does not appear in the Figure. The corrected Figure 14 appears below.

The authors apologize for this error and state that this does not change the scientific conclusions of the article in any way. The original article has been updated.

Copyright (๔ 2021 Mosquera Giménez, Vélez-Belchí, Rivera, Piñeiro, Fajar, Caínzos, Balbín, Jiménez Aparicio, DominguezCarrió, Blasco-Ferre, Carreiro-Silva, Morato, Puerta and Orejas. This is an open-access article distributed under the terms of the Creative Commons Attribution License (CC BY). The use, distribution or reproduction in other forums is permitted, provided the original author(s) and the copyright owner(s) are credited and that the original publication in this journal is cited, in accordance with accepted academic practice. No use, distribution or reproduction is permitted which does not comply with these terms. 
Mosquera Giménez et al.

Corrigendum: Ocean Circulation Over North
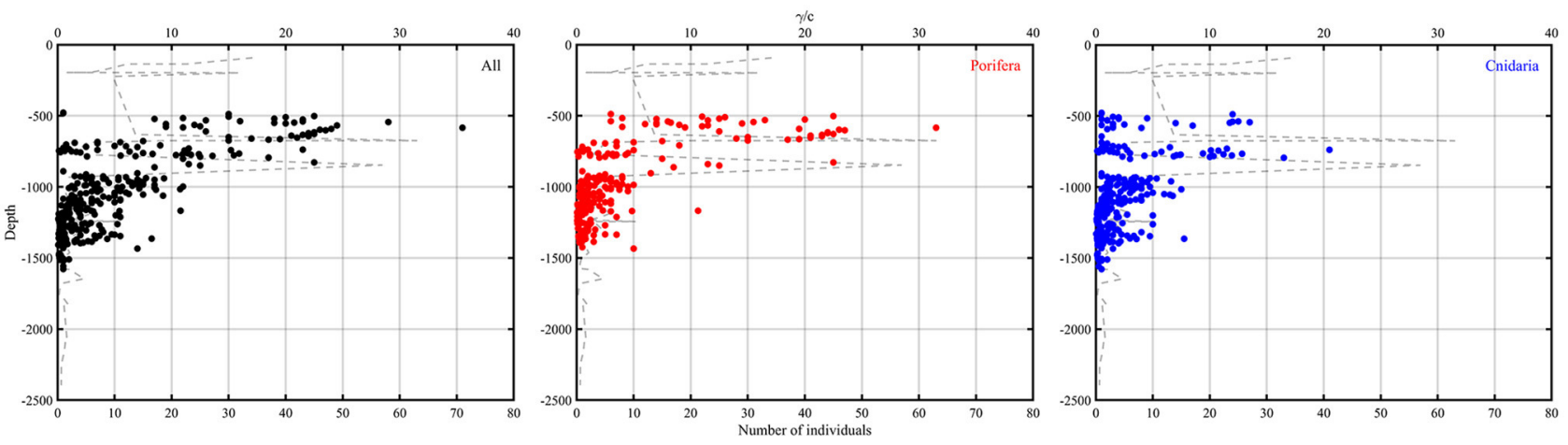

FIGURE 14 | Vertical profiles representing the abundance of benthic invertebrates averaged in $2 \mathrm{~m}$ bins for all phyla (A), porifera (B), and cnidaria (C) in Formigas seamount. The gray dashed line represents the coefficient between the bottom slope and the angle of propagation of the internal waves $(\gamma / c)$.

Frontiers in Marine Science | www.frontiersin.org

2

February 2021 | Volume 8 | Article 665980 